\title{
Problematika Pendidikan Agama Islam di Daerah Minoritas Muslim
}

\author{
Rizkika Zakka Agustin ${ }^{1}$, Kasuwi Saiban², Mufarrihul Hazin ${ }^{3}$ \\ 1,2,3 STAI Ma'had Aly Al Hikam Malang \\ e-mail: icha0826@gmail.com
}

\begin{abstract}
ABSTRAK: Pendidikan agama Islam ialah pondasi utama untuk membentuk karakter manusia supaya menjadi pribadi yang berakhlakul karimah dan bermanfaat bagi sekitar, sebagaimana yang disabdakan oleh Rasulullah SAW bahwasanya sebaik-baik manusia adalah yang bermanfaat bagi yang lainnya. Pelaksanaan pendidikan agama Islam ini tentunya banyak menemui problem atau masalah. Dalam jurnal ini akan dikaji mengenai problematika pendidikan Agama Islam di daerah minoritas Muslim. Metode yang digunakan pada penelitian ini yaitu kajian kepustakaan (library research) dengan pendekatan analisis konten (content analysis). Tujuan penelitian ini yaitu untuk mengidentifikasi problematika pendidikan agama Islam di daerah minoritas Muslim beserta solusinya. Secara umum problematika yang dihadapi dalam proses pendidikan Agama Islam di daerah minoritas Muslim yaitu adanya kebijakan yang diskriminatif oleh pemerintah setempat yang tentunya kurang menguntungkan lembaga-lembaga pendidikan Islam (madrasab), kurangnya guru PAI, kurangnya atau babkan tidak adanya sarana prasarana penunjang proses pembelajaran pendidikan Agama Islam, lingkungan sekolah yang kurang mendukung serta kurangnya partisipasi masyarakat sekitar yang kurang bisa menerima pendidikan Agama Islam itu sendiri. Adapun solusi yang bisa dilakukan yaitu adanya peran aktif pemerintah untuk menegakkan kebijakan yang bepibak pada keberlangsungan lembaga-lembaga pendidikan Islam di daerah minoritas Muslim, dukungan prima dari sekolah kepada guru PAI dalam melaksanakan proses pendidikan agama Islam, bagi madrasah yang berada di daerah minoritas Muslim diharapkan mampu menggunakan strategi khusus supaya tetap eksis, serta bagi guru PAI sendiri dibarapkan juga bisa kreatif dan inovatif dalam melaksanakan pembelajaran PAI dan mampu bersikap terampil, ulet, adaptif, dan toleran dalam kehidupan sosial, tanpa mengorbankan akidah.
\end{abstract}

Kata Kunci: Problematika PAI, minoritas Muslim, solusi.

\section{PENDAHULUAN}

Pada awalnya istilah "pendidikan" berasal dari bahasa Yunani yaitu paedagogie yang artinya bimbingan yang diberikan kepada anak. Dalam bahasa Inggris, istilah "pendidikan" diterjemahkan sebagai education, yang artinya pengembangan atau bimbingan. Selanjutnya, bahasa Arab menyebut istilah pendidikan sebagai al-ta'lim, al-tarbiyah dan al-ta'dib. Al-ta'lim artinya pengajaran yang bersifat pemberian atau penyampaian pengetahuan dan ketrampilan. Al-tarbiyah mengandung arti mengasuh dan mendidik. Sedangkan Al-ta'dib lebih condong pada proses mendidik yang bermuara pada penyempurnaan akhlak atau moral peserta didik. ${ }^{1}$ Tetapi dalam hal ini, istilah tarbiyah lebih sering dipakai sebagai terjemahan dari kata "pendidikan".

Pendidikan agama Islam ialah pondasi utama untuk membentuk karakter manusia supaya menjadi pribadi yang berakhlakul karimah dan bermanfaat bagi sekitar, sebagaimana yang disabdakan oleh Rasulullah SAW bahwasanya sebaik-baik manusia adalah yang bermanfaat bagi yang lainnya. Selain itu, pendidikan agama Islam juga mampu dijadikan

${ }^{1}$ C Thoha, dkk. 1999. Metodologi Pengajaran Agama. (Pustaka Pelajar)

2 S Nizar. 2001. Pengantar Dasar-Dasar Pemikiran Pendidikan Islam. Gaya Media Pratama. 
sebagai ujung tombak kemajuan agama Islam di masa mendatang. Pendidikan Islam yang disampaikan dengan baik akan mencetak para cendekiawan muslim yang cemerlang, baik akhlak maupun pemikirannya, seperti pada masa keemasan Islam terdahulu.

Menurut Undang - Undang Nomor 20 Tahun 2003 tentang Sistem Pendidikan Nasional Pasal 5 ayat 1 dan ayat 3, disebutkan bahwa "setiap warga negara mempunyai hak yang sama untuk memperoleh pendidikan yang bermutu dan melalui layanan khsusus, termasuk warga negara yang berada di daerah atau komunitas adat terpencil, terbelakang, di daerah konflik, bencana alam, bencana sosial dan tidak mampu dari segi ekonomi”. Untuk itu, dalam rangka merealisasikan amanat undang - undang tersebut, negara berkewajiban membangun akses pendidikan yang layak bagi seluruh warga negara dimanapun dan dalam kondisi bagaimanapun, termasuk kelompok minoritas yang disebabkan perbedaan suku, ras, agama, sosial, politik dan lain sebagainya.

Dalam rangka memenuhi amanat undang-undang tersebut, pemerintah, dalam hal ini kementerian agama, telah berusaha memperbaiki dan membenahi penyelenggaraaan pendidikan madrasah yang tumbuh dari masyarakat dan tersebar di seluruh penjuru tanah air, tanpa terkecuali juga di daerah-daerah minoritas Muslim. Namun penyelenggaraan pendidikan agama islam pada madrasah di daerah minoritas Muslim umumnya masih memiliki kualitas yang rendah. Oleh sebab itu, penelitian ini bertujuan untuk mengidentifikasi problematika apa saja yang muncul dalam pendidikan agama islam di daerah - daerah minoritas serta bagaimana solusianya.

\section{Metode}

Dalam penelitian ini, metode yang digunakan yaitu library reserach atau penelitian kepustakaan. Penelitian kepustakaan ini merupakan serangkaian kegiatan yang berkenaan dengan metode pengumpulan data pustaka, membaca dan mencatat serta mengolah bahan penelitiannya. ${ }^{3}$ Sholeh menyatakan bahwa penelitisn kepustakaan (library research) yaitu penelitian yang menggunakan cara untuk mendapatkan data informasi dengan menempatkan fasilitas yang ada di perpustakaan, seperti buku, majalah, dokumen, catatan kisah-kisah sejarah atau penelitian penelitian kepustakaan murni yang terkait dengan obyek penelitian. Penelitiaan ini memanfaatkan sumber perpustakaan untuk memperolah data penelitian. ${ }^{4}$

Adapun pendekatan yang digunakan dalam penelitian ini yaitu model pendekatan content analysis atau kajian isi yang bersifat pembahasan yang mendalam terkait isi suatu informasi tertulis atau tercetak dalam media massa. Analisis ini biasannya digunakan pada penelitian kualitatif. Secara umum, kajian isi diartikan sebagai metode pendekatan yang meliputi semua analisis mengenai isi teks, namun di sisi lain analisis isi juga digunakan untuk mendeskripsikan pendekatan analisis khusus.

\section{TEMUAN}

\section{A. Hakekat Minoritas dalam Konteks Minoritas Muslim}

Istilah "minoritas" diartikan sebagai bagian dari penduduk yang beberapa ciricirinya berbeda dan umumnya mendapat perlakuan berbeda. Beberapa ciri-ciri yang berbeda tersebut bisa berupa bentuk fisik, seperti warna kulit dan bahasa. Menurut Theodorson \& Theodorson, kelompok minoritas atau minoriy groups yaitu kelompokkelompok yang diakui berdasarkan perbedaan ras, agama, atau suku bangsa, yang mengalami kerugian sebagai akibat prasangka (prejudice) atau biasa dikenal dengan istilah diskriminasi. Adapun pengertian minoritas menurut Pelapor Khusus PBB untuk perlindungan hak minoritas, Fransesco Capotorti (Solikhin, 2016), yaitu: “ A group

\footnotetext{
${ }^{3}$ Mahmud. 2011. Metode Penelitian Pendidikan. (Pustaka Setia)

${ }^{4}$ A.R Sholeh. 2005. Pendidikan Agama dan Pengembangn untuk Bangsa. (PT. Raja Grafindo Persada), 63
} 
numerically inferior to the rest of the population of a state, in a non dominant position, whose members being nationals of the state-posses ethnic, religion or linguistic characteristic differing from those of the rest of the population and show, if only implicity a sense of solidarity, direct toward preserving their culture, traditions, religion, or language. ${ }^{\circ 5}$ Minoritas dimaksudkan sebagai: pertama, secara numerik jumlahnya lebih kecil dari sisa populasi lainnya dalam suatu negara. Kedua, posisinya tidak dominan dalam konteks negara. Ketiga, adanya perbedaan etnik, agama, dan budaya dengan populasi lainnya. Keempat, memiliki solidaritas agama, bahasa, tradisi, budaya, dan kepentingan untuk meraih persamaan di muka umum dengan populasi di luarnya.

Minoritas Muslim merupakan bagian penduduk yang berbeda dari penduduk lainnya karena anggota-anggotanya mengakui bahwa Muhammad SAW putra Abdullah menjadi utusan Allah yang terakhir serta meyakini bahwa ajaran Muhammad SAW adalah benar, namun sering mendapat perlakuan berbeda dari kelompok-kelompok lain yang tidak mempunyai keyakinan seperti itu. ${ }^{6}$

Pendapat yang berbeda disampaikan oleh Ahmad al-Usairy. Menurutnya, minoritas Muslim ialah kelemahan dan tidak adanya peran, baik ekonomi, politik, maupun sosial, kaum muslim di suatu wilayah. ${ }^{7}$ Pendapat ini diperkuat oleh tulisan Indriana Kartini, yang mengutip pendapat Gerr, bahwa status minoritas Muslim tidak hanya berkaitan dengan jumlah komunitas Muslim yang lebih sedikit dibandingkan dengan seluruh populasi penduduk di suatu wilayah tertentu, tetapi terdapat beberapa asumsi lain terkait status minoritas, yakni dilihat dari aspek lain diantaranya: budaya, politik, sosial dan ekonomi. ${ }^{8}$

\section{B. Fiqh Minoritas}

Beberapa waktu terakhir, sejumlah Ulama mencetuskan fiqh al-aqalliyyat atau fiqh minoritas seperti yang disampaikan oleh Dr. Taha Jabir al-Alwani di Amerika Serikat dalam bukunya yang berjudul Towards A Fiqh For Minorities: Some Basic Reflections, serta Dr. Yusuf al-Qardhawi dengan bukunya Fi Fiqh al-aqalliyyat al-Muslimah.

Fiqh minoritas ini bertujuan untuk meringankan beban dan mengurangi kesulitan-kesulitan umat Islam yang tinggal di wilayah mayoritas non-Muslim. Oleh sebab itu, diharapkan semakin banyak para ulama dan cendekiawan Muslim yang memberikan perhatian lebih terkait fiqh minoritas ini serta melakukan kajian yang lebih mendalam.

Oleh karena kondisi umat Islam minoritas tidak selamanya sama dengan kondisi umat Islam mayoritas, maka diperlukan adanya penyesuaian. Umat Islam yang tinggal di wilayah minoritas Muslim sebaiknya tetap menjaga interaksi dan pergaulan yang baik serta menghindari konflik dengan warga non-Muslim. Fiqh minoritas ini juga mengatur masalah umat Islam dalam kaitannya untuk menjaga hubungan baik dengan warga nonMuslim. Seyogyanya, umat Muslim minoritas mampu memposisikan dan menyesuaikan diri serta bisa membedakan antara aqidah dan pergaulan. Selain itu, umat Muslim minoritas juga sebaiknya mempertahankan identitas budaya wilayah dimana mereka tinggal, tentunya dengan tetap memegang teguh ajaran dan nilai - nilai aqidah Islam.

Di samping itu, diperlukan pula peran pemerintah untuk menjaga dan memperlakukan kelompok Muslim minoritas ini secara adil dan proposional sehingga $1(2)$

5 A Solikhin. 2016. Islam, Negara, dan Perlindungan Hak-Hak Islam Minoritas. Journal of Governance,

6 Mubasirun. 2015. Persoalan Dilematis Muslim Minoritas dan Solusinya. Episteme: Jurnal Pengembangan Ilmu Keislaman, 10(1)

7 Al-Usairy. 2013. Sejarah Islam, (terjemahan Samson Rohman. Akbar Media)

${ }^{8}$ I Kartini. 2011. Dinamika Kehidupan Minoritas Muslim di Bali. Masyarakat Indonesia: Jurnal IlmuImu Sosial Indonesia, 37(2) 
umat Islam minoritas bisa menyampaikan aspirasi dengan cara hikmah dan bijaksana sesuai dengan ajaran dan nilai-nilai aqidah Islam.

\section{Problematika Pendidikan Agama Islam di Daerah Minoritas Muslim}

Seperti kita ketahui bahwa negara Indonesia adalah negara dengan masyarakat yang majemuk, artinya masyarakat yang tersusun atas berbagai identitas sosial, seperti identitas keagamaan, keetnisan, profesi, dan lain sebagainya. Selanjutnya akan muncul pemikiran sosiologis terkait adanya masyarakat majemuk ini, yakni konsekuensi konsekuensi terhadap beberapa hal penting mengenai kehidupan sosial, diantaranya: stabilitas dan harmoni sosial. Hal yang pasti yaitu munculnya masalah dalam relasi mayoritas-minoritas. Contohnya umat Islam yang sulit mendirikan masjid di wilayah minoritas Muslim, atau umat Muslim minoritas yang tidak diperbolehkan menggunakan pengeras suara pada saat mengumandangkan adzan, dan lain sebagainya.

Lebih spesifik dalam hal Penyelenggaraan Pendidikan Agama Islam di daerah Muslim minoritas, tentu juga ditemui berbagai permasalahan. Misalnya tidak adanya tempat ibadah muslim di sekolah, pada saat pelaksanaan shalat jumat, siswa muslim tidak diberi kesempatan untuk shalat karena proses pembelajaran masih berlangsung. Bahkan ruang kelas khusus bagi siswa untuk mata pelajaran Pendidikan Agama Islam juga tidak tersedia. Selanjutnya masalah terbesar dalam mengoptimalkan pembelajaran PAI yaitu kurangnya atau bahkan tidak adanya guru PAI di beberapa sekolah (Rusmayani, 2019), bahkan di suatu sekolah daerah minoritas Muslim ditemukan guru pendidikan agama Islam yang bukan Muslim. ${ }^{9}$

Selain itu para guru PAI di daerah minoritas Muslim itu sendiri juga tidak terlepas dari berbagai permasalahan yang menjerat mereka. Wahib melakukan penelitian tentang pergulatan pendidikan agama Islam yang ada di Bali. Berdasarkan penelitian tersebut, ditemukan bahwa para guru Pendidikan Agama Islam di Bali juga menghadapi berbagai problem yang meliputi berbagai ranah kehidupan mereka, diantaranya sebagai berikut:

1. Di sekolah atau kelas tidak mendapatkan meja kerja sendiri, dianggap tidak ada, tidak pernah mendapatkan posisi struktural yang berarti, dilibatkan sebagai panitia hanya sekedar untuk peran-peran kecil.

2. Input siswa dengan kemampuan rendah

3. Situasi yang tidak mendukung, misalnya tidak adanya tempat mengajar yang memadahi, mengajar di luar jam belajar, proses belajar mengajar mata pelajaran PAI yang bersamaan dengan latihan kesenian yang menggunakan musik dengan suara keras, dan lain-lain.

4. Tidak adanya mushalla

5. Saat tiba shalat jumat, proses pembelajaran masih tetap berlangsung

6. Problem sosial lainnya antara lain: realitas sosial masyarakat sekitar yang berlawanan dengan nilai-nilai Islam yang diajarkan di sekolah, lingkungan masyarakat adat yang kolot, mengajar di berbagai sekolah untuk mengejar target jam kerja, atau memenuhi kebutuhan sekolah-sekolah yang tidak memiliki guru PAI. ${ }^{10}$

Selain itu, Azyumardi Azra berpendapat bahwa pemberlakuan otonomi atau desentralisasi pendidikan dapat menimbulkan berbagai dampak terhadap Pendidikan Islam, termasuk madrasah dan pondok pesantren. Hal ini terjadi karena desentralisasi

\footnotetext{
9 R Rusmayani. 2019. The Potrait of PAI and Budi Pekerti's Learning in Public School on Earth Minority. Proceedings of Annual Conference for Muslim Scholars, 3(1)

${ }^{10}$ A Wahib. 2011. Pergulatan Pendidikan Agama Islam di Kawasan Minoritas Muslim. Walisongo, $19(2)$
} 
pendidikan tidak melibatkan lembaga - lembaga pendidikan Islam termasuk madrasah atau pesantren. Di sisi lain, lembaga-lembaga pendidikan Islam tersebut harus mengikuti perubahan tersebut. Terlebih bagi lembaga-lembaga pendidikan Islam di daerah minoritas Muslim, kondisi tersebut tentu sangat tidak menguntungkan. Pemerintah daerah yang dikuasai oleh kelompok mayoritas non-Muslim pasti sangat kecil kemungkinannya memberikan perhatian terhadap lembaga-lembaga pendidikan Islam, sehingga kebijakan-kebijakan nya akan sangat diskriminatif dan kurang bahkan tidak pernah menyentuh lembaga-lembaga pendidikan Islam. Kebijakan - kebijakan tersebut semakin diskriminatif manakala Pemerintah daerah yang masih salah tafsir dalam memahami peraturan Mendagri yang sebetulnya tidak melarang Pemerintah daerah memberikan bantuan kepada lembaga-lembaga pendidikan Islam (madrasah).

Terlebih lagi, Kementerian Agama selaku instansi pemerintah yang membawahi madrasah itu sendiri juga tidak memiliki penganggaran memadahi bagi penyelenggaraan madrasah, sehingga sulit melakukan realisasi anggaran berdasarkan asas keadilan dan pemerataan, serta terjadi perlakuan yang berbeda antara madrasah negeri dan swasta, antara madrasah perkotaan dan madrasah pedesaan, dan antara madrasah di daerah mayoritas Muslim dan madrasah di daerah minoritas Muslim. ${ }^{11}$

Di samping permasalahan diskriminasi, masalah besar lain yang dihadapi madrasah pasca diberlakukannya otonomi daerah yaitu peran atau partisipasi masyarakat. Bagi masyarakat mayoritas non muslim, Pendidikan Agama Islam tidak hanya dijadikan sebagai bukan kebutuhan mereka, tetapi juga dipandang membahayakan keyakinan mereka sehingga harus dijauhi dan dihindari, khususnya bagi mereka yang masih berpegang teguh pada keyakinan agama mereka. Hal ini berimbas dari sisi input siswa, lembaga pendidikan Islam akan sangat sulit memperoleh siswa dari kalangan nonMuslim. ${ }^{12}$

\section{Solusi Atas Problematika Pendidikan Agama Islam di Daerah Minoritas Muslim}

Tentunya adanya peran serta kerjasama dari berbagai pihak untuk menganggulangi problematika Pendidikan Agama Islam di daerah minoritas Muslim ini, diantaranya:

1.Pemerintah (Kementerian Agama)

Satuan Kerja Kementerian Agama di wilayah setempat hendaknya bekerja sama dengan pihak sekolah untuk melakukan pendataan secara cermat siswa Muslim di sekolah-sekolah mayoritas non-Muslim. Hal ini bertujuan untuk memberikan jaminan kepada setiap siswa Muslim agar mendapatkan haknya, berupa Pendidikan Agama Islam di sekolah, sesuai dengan amanat Undang-Undang Sistem Pendidikan Nasional. Di samping itu, kementerian agama di perwakilan wilayah terkait juga perlu berdioalog dengan pihak sekolah tentang fasilitas serta sarana dan prasarana tempat ibadah bagi para guru PAI dan siswa Muslim. Tentunya yang terpenting dalam hal ini yaitu peran aktif pemerintah sebagai pemegang tampuk kekuasaan tertinggi untuk merancang dan menentukan kebijakan - kebijakan yang tidak diskriminatif dan merangkul serta berpihak kepada lembaga-lembaga pendidikan Islam terutama madrasah di daerah minoritas Muslim. Dengan demikian mereka bisa tetap eksis di tengah masyarakat mayoritas non-Muslim serta lebih khusus lagi, proses pendidikan Agama Islam bisa terlaksana dengan optimal.

2.Pihak Sekolah

a. Sekolah Umum dengan Mayoritas non-Muslim

${ }^{11}$ U Hidayati. 2015. Penyelenggaraan Madrasah Di Daerah Minoritas Muslim. Edukasi, 13(2)

12 B Arifin. 2019. Strategi Pengembangan Lembaga Pendidikan Islam di Daerah Minoritas Muslim dan Kawasan Elite. Falasifa, 10(2). 
Stakeholders sekolah diharapkan juga memberikan dukungan yang prima kepada para guru Pendidikan Agama Islam. Dukungan ini bisa direalisasikan dengan penyusunan manajemen kurikulum serta jadwal yang tidak diskriminatif terhadap guru PAI. Dengan demikian, guru Pendidikan Agama Islam bisa bekerja dengan lebih optimal. Selain itu, pihak sekolah juga perlu melakukan konsultasi dengan pihak instansi vertikal terkait pemenuhan sarana prasarana untuk mata pelajaran Pendidikan Agama Islam supaya tujuan Pendidikan Agama Islam bisa tercapai dengan baik.

b.Lembaga Pendidikan Islam (Madrasah) yang Berada di Wilayah Minoritas Muslim

Berbeda dengan sebelumnya, kondisi saat ini yaitu apabila terdapat lembaga pendidikan Islam, sekolah atau madrasah, yang berada di daerah minoritas Muslim. Tentunya hal ini menjadi tantangan tersendiri bagi madrasah yang berada di daerah minoritas Muslim untuk bisa tetap survive. Terlepas dari dukungan pemerintah, madrasah juga harus inovatif serta mempunyai strategi khusus dan jitu sehingga misi pendidikan Islam bisa terlaksana dengan baik, lebih jauh lagi kiprah madrasah secara umum bisa tetap eksis di tengah masyarakat mayoritas non-Muslim. Contoh strategi yang bisa dilakukan yaitu merekrut guru-guru dari kelompok mayoritas nonMuslim di wilayah setempat. Hal ini dilakukan dengan tujuan untuk menghilangkan atau setidaknya meminimalisasi resistensi masyarakat sekitar yang notabene beragama mayoritas non-Muslim. Kelompok minoritas memang harus pandai beradaptasi dan membaur dengan kelompok mayoritas. Strategi lain yang bisa dilakukan yaitu strategi kooperatif, adaptif, dakwah kultural, akulturatif, sikap toleran, mengalah dan lain sebagainya. Strategi - strategi di atas tentunya sudah direalisasikan dan dibuktikan oleh lembaga-lembaga pendidikan Islam di daerah minoritas Muslim sehingga mereka sampai sekarang bisa tetap eksis dalam melaksanakan proses pendidikannya, salah satu contohnya yaitu Madrasah Tsanawiyah Bali Bina Insani. ${ }^{13}$ (Syarifuddin, 2019)

\section{Para Guru PAI}

Bisa dikatakan bahwa guru PAI merupakan penentu utama keberhasilan penyelenggaraan pendidikan Agama Islam. Di tangan merekalah harapan besar akan perbaikan akhlak generasi penerus diletakkan. Dengan adanya tantangan berupa kondisi minoritas ini, para guru PAI diharapkan bisa lebih kreatif serta inovatif mengembangkan kurikulum pendidikan agama Islam dengan mengimplementasikan strategi dan metode pembelajaran yang cocok sehingga misi pendidikan agama Islam mampu terlaksana dengan optimal. Selain itu guru PAI juga sebaiknya bisa lebih partisipatif dalam berbagai program yang diselenggarakan oleh sekolah, dengan demikian kehadirannya dirasakan lebih kontributif secara kelembagaan. Di samping itu, guru PAI harus mampu terampil dan ulet dalam kehidupannya, terutama bisa adaptif, toleran serta mampu membaur dengan lingkungan sekitar, tanpa mengorbankan aqidah Islam sebagai identitas utama mereka. Justru guru PAI harus mampu menunjukkan dan membuktikan bahwa agama Islam merupakan agama yang paling toleran dan sangat menghormati pemeluk agama lain.

\section{KESIMPULAN}

Berdasarkan studi pustaka yang dilakukan pada penelitian ini dapat disimpulkan bahwa problematika pendidikan agama Islam di daerah minoritas Muslim diantaranya: 1)

\footnotetext{
13 Syaifuddin, et al. 2019. Strategi Pemasaran Pendidikan Madrasah Tsanawiyah Bali Bina Insani di Daerah Minoritas-Muslim Tabanan Bali. Jurnal Pendidikan Agama Islam (Journal of Islamic Education Studies), $7(2)$
} 
problem yang dihadapi oleh guru PAI, yaitu perlakuan diskriminatif di lingkungan kerja; input siswa dengan kemampuan rendah; situasi yang tidak mendukung, misalnya tidak adanya tempat mengajar yang memadahi, mengajar di luar jam belajar, proses belajar mengajar mata pelajaran PAI yang bersamaan dengan latihan kesenian yang menggunakan musik yang keras; tidak adanya mushalla, saat tiba shalat jumat, proses pembelajaran masih tetap berlangsung; serta problem sosial lainnya, seperti: realitas sosial masyarakat sekitar yang berlawanan dengan nilai-nilai Islam yang diajarkan di sekolah, lingkungan masyarakat adat yang kolot, mengajar di berbagai sekolah untuk mengejar target jam kerja, atau memenuhi kebutuhan sekolah-sekolah yang tidak memiliki guru PAI. 2) problem yang dihadapi sekolah umum di daerah minoritas Muslim yaitu kurangnya atau bahkan tidak adanya guru PAI serta kurangnya sarana dan prasarana untuk menunjang proses pendidikan PAI. 3) problem yang dihadapi lembaga pendidikan Islam (madrasah) di daerah minoritas Muslim, yaitu: kebijakan diskriminatif pemerintah setempat yang tentunya kurang berpihak pada madrasah, serta kurangnya partisipasi masyarakat sekitar sehingga madrasah kesulitan mendapatkan siswa, terutama dari kelompok mayoritas non-Muslim.

Adapun solusi yang bisa ditawarkan antara lain: 1) peran aktif pemerintah, sebagai pemegang tampuk kekuasaan tertinggi, untuk merancang dan menentukan kebijakan yang tidak diskriminatif dan berpihak pada eksistensi lembaga pendidikan Islam, terutama madrasah di daerah minoritas Muslim, 2) pihak sekolah umum dengan mayoritas non muslim diharapkan bisa memberikan dukungan prima kepada para guru PAI baik secara moral dan material, sehingga proses pendidikan Agama Islam dapat terlaksana dengan optimal. 3) untuk lembaga pendidikan Islam (madrasah) yang berada di wilayah minoritas Muslim, bisa diupayakan dengan cara mengimplementasikan strategi khusus yang jitu sehingga mereka bisa tetap eksis di tengah masyarakat mayoritas non-Muslim. 4) yang terpenting, guru PAI sendiri diharapkan bisa kreatif dan inovatif dalam melaksanakan pembelajaran PAI serta mampu bersikap terampil, ulet, adaptif, serta toleran dalam kehidupan sosial, tentunya tanpa mengorbankan akidah Islam.

\section{REFERENSI}

Al-Usairy, A. 2013. Sejarah Islam, terjemahan Samson Rohman. Akbar Media.

Arifin, B. 2019. Strategi Pengembangan Lembaga Pendidikan Islam di Daerah Minoritas Muslim dan Kawasan Elite. Falasifa, 10(2)

Hidayati, U. 2015. Penyelenggaraan Madrasah di Daerah Minoritas Muslim. Edukasi, 13(2)

Kartini, I. 2011. Dinamika Kehidupan Minoritas Muslim di Bali. Masyarakat Indonesia: Jurnal Ilmu-Imu Sosial Indonesia, 37(2)

Mahmud. 2011. Metode Penelitian Pendidikan. Pustaka Setia.

Mubasirun. 2015. Persoalan Dilematis Muslim Minoritas dan Solusinya. Episteme: Jurnal Pengembangan Ilmu Keislaman, 10(1)

Nizar, S. 2001. Pengantar Dasar-Dasar Pemikiran Pendidikan Islam. Gaya Media Pratama.

Rusmayani, R. 2019. The Potrait of PAI and Budi Pekerti's Learning in Public School on Earth Minority. Proceedings of Annual Conference for Muslim Scholars, 3(1)

Sholeh, A.R. 2005. Pendidikan Agama dan Pengembangn untuk Bangsa. PT. Raja Grafindo Persada.

Solikhin, A. 2016. Islam, Negara, dan Perlindungan Hak-Hak Islam Minoritas. Journal of Governance, 1(2) 
Syaifuddin, et al. 2019. Strategi Pemasaran Pendidikan Madrasah Tsanawiyah Bali Bina Insani di Daerah Minoritas-Muslim Tabanan Bali. Jurnal Pendidikan Agama Islam (Journal of Islamic Education Studies), 7(2)

Thoha, C., dkk. 1999. Metodologi Pengajaran Agama. Pustaka Pelajar.

Wahib, A. 2011. Pergulatan Pendidikan Agama Islam di Kawasan Minoritas Muslim. Walisongo, 19(2) 